\title{
Detection of extended spectrum beta-lactamases and resistance in members of the Enterobacteriaceae family isolated from healthy sheep and dogs in Umuarama, Paraná, Brazil
}

\author{
Deteç̧ão de beta-lactamases de espectro estendido e resistência \\ as quinolonas mediada por plasmídeos em membros da família \\ Enterobacteriaceae isolados de ovinos e cães sadios de propriedades \\ rurais da região de Umuarama, Paraná, Brasil
}

\author{
Patrícia Alves de Oliveira ${ }^{1}$; Rodrigo Assunção Moura ${ }^{2}$; Graziela Vendrame \\ Rodrigues $^{3}$; Karoline Franciani Cardoso Lopes ${ }^{4}$; Melissa Marchi Zaniolo ${ }^{5}$; Kariny \\ Aparecida Jardim Rubio ${ }^{6}$; Eduardo Herrera Dias ${ }^{7}$; Leila Alves de Oliveira ${ }^{8}$; \\ Roberta Torres Chideroli ${ }^{9}$; Daniela Dib Gonçalves ${ }^{10^{*}}$
}

\begin{abstract}
Bacterial resistance is a primary public health concern worldwide. Within this context, pets and breeding animals act as reservoirs for multidrug-resistant bacteria (MR), such as those producing extended spectrum beta-lactamases (ESBL) and those presenting plasmid-mediated quinolone resistance (PMQR). The aim of this study was to detect the presence of ESBL and PMQR in members of the Enterobacteriaceae family, isolated from healthy sheep and dogs from non-intense farming rural properties in the Umuarama region of Paraná, Brazil. A total of 81 oral and rectal swabs from dogs and sheep from 11 small rural properties were analyzed. These swabs were inoculated in tubes containing brain heart infusion broth (BHI), and the resulting cultures were inoculated on MacConkey agar (MAC) supplemented with $10 \mu \mathrm{g} / \mathrm{mL}$ cefotaxime for the selection of ESBL producers. The cells were also plated on MAC supplemented with $50 \mu \mathrm{g} / \mathrm{mL}$ nalidixic acid for selecting quinolone-resistant enterobacteria. The bacterial isolates were subjected to biochemical identification tests, antibiograms, double-disk synergic tests, and polymerase chain reaction analysis for resistance-inducing genes ( $b l a_{\mathrm{ESBL}}, q n r$, and genes encoding efflux pump and acetylases). Four (5.00\%) bacterial isolates (3 Escherichia coli and 1 Morganella morganii) resistant to cephalosporins and/or quinolones were identified; of these, three $(75 \%)$ isolates were from sheep and one $(25 \%)$ from a dog. These findings indicate the presence of MR bacteria in the normal microbiota of the animals studied. Animals colonized with such bacteria can
\end{abstract}

\footnotetext{
${ }^{1}$ Bióloga, Discente do Mestrado em Ciência Animal, Universidade Paranaense, UNIPAR, Umuarama, PR, Brasil. E-mail: patricia_d_oliver@hotmail.com

2 Pós-doutorado, Pesquisador do PNPD/CAPES, Mestrado em Ciência Animal, UNIPAR, Umuarama, PR, Brasil. E-mail: rodrigomoura81@me.com

${ }^{3}$ Biomédica, Discente do Mestrado em Ciência Animal, UNIPAR, Umuarama, PR, Brasil. E-mail: grazielavr@hotmail.com

${ }^{4}$ Bióloga, Discente do Mestrado em Ciência Animal, UNIPAR, Umuarama, PR, Brasil. E-mail: karol .lopes@hotmail.com

${ }_{5}^{5}$ Médica Veterinária, Discente do Mestrado em Ciência Animal, UNIPAR, Umuarama, PR, Brasil. E-mail: melissaz.vet@gmail. com

${ }^{6}$ Médica Veterinária, UNIPAR, Umuarama, PR, Brasil. E-mail: karinyemarcos@hotmail.com

7 Discente da Universidade Estadual de Maringá, UEM, Umuarama, PR, Brasil. E-mail: eduhd herreradias@hotmail.com

${ }^{8}$ Médica Veterinária, Discente do Mestrado em Ciência Animal, UNIPAR, Umuarama, PR, Brasil. E-mail: jaconeti@hotmail.com

9 Médica Veterinária, Programa de Pós-Graduação em Ciência Animal, Universidade Estadual de Londrina, UEL, Londrina, PR. E-mail: robertaa_tc@hotmail.com

${ }^{10}$ Médica Veterinária, Prof ${ }^{a}$ do Mestrado em Ciência Animal, UNIPAR, Umuarama, PR. E-mail: danieladib@unipar.br

* Author for correspondence
} 
contribute to the dissemination of antimicrobial resistance to other animals, environment, and/or human beings and can harbor endogenous infections in unfavorable conditions, which have poor prognosis due to the limited therapeutic options.

Key words: Antibiotics. Dogs. Drug resistance. Enterobacteriaceae. ESBL. Escherichia coli. Quinolones. Morganella morganii. Sheep.

\section{Resumo}

Resistência bacteriana é considerado o maior problema de saúde pública mundial da atualidade, sendo os relatos de infecções e surtos causados por bactérias multirresistentes cada vez mais frequentes na clínica veterinária e humana. Neste contexto, animais de companhia e criação podem atuar como reservatório de bactérias multirresistentes, como as produtoras de beta-lactamases de espectro estendido (ESBL) e as que apresentam resistência as quinolonas mediada por plasmídeos (PMQR). O objetivo deste trabalho foi detectar beta-lactamases de espectro estendido e resistência as quinolonas mediada por plasmídeos em membros da família Enterobacteriaceae isolados de ovinos e cães de propriedades rurais não tecnificadas da região de Umuarama, Paraná, Brasil. Foram analisados 81 swabs de cães e ovinos provenientes de 11 pequenas propriedades rurais da região de Umuarama (PR). Os swabs foram inoculados em caldo Brain Heart Infusion (BHI) e o crescimento obtivo foi em seguida semeado em placas de Petri contendo ágar MacConkey (MC) acrescido de cefotaxima $10 \mu \mathrm{g} / \mathrm{mL}$ para seleção de bactérias gram-negativas produtoras de ESBL; e placas contendo $\mathrm{MC}$ acrescido de ácido nalidíxico $50 \mathrm{~g} / \mathrm{mL}$ para seleção de bactérias gram-negativas resistentes as quinolonas. Os isolados bacterianos obtidos foram submetidos a testes de antibiograma pelo método de disco-difusão em ágar, teste sinérgico do duplo-disco e reação em cadeia da polimerase (PCR) para genes que conferem resistência do tipo ESBL e para quinolonas. Dos 81 swabs coletados foi possível detectar quatro $(4,97 \%)$ isolados bacterianos (3Escherichia coli e 1 Morganellamorganii) resistentes a cefalosporinas e/ou quinolonas. Destes isolados, três $(75 \%)$ eram de ovinos e um $(25 \%)$ de cão. Os resultados encontrados indicam a presença de cepas multirresistentes na microbiota normal dos animais estudados. Nesta condição, os animais colonizados podem contribuir para disseminação dos agentes bacterianos para outros animais, ambiente e/ou homem, ou em uma situação desfavorável o hospedeiro pode adquirir uma infecção endógena, com prognóstico desfavorável decorrente da falha terapêutica mediada pela expressão de genes de resistência para antibacterianos considerados de última escolha terapêutica.

Palavras-chaves: Antimicrobianos. Cães. ESBL. Enterobacteriaceae. Escherichia coli. Morganella morganii. Ovinos. Quinolonas. Resistência bacteriana.

\section{Introduction}

Antimicrobial resistance is considered the primary public health issue in the current global scenario. Infections and outbreaks caused by multidrug-resistant bacteria are frequent in both human and veterinary medicine, and in some cases, the isolated microorganisms are resistant to all available antimicrobial drugs (SOUZA, 2010; JONG et al., 2011; TEO et al., 2012; WHO, 2014).

The emergence and selection of multidrugresistant strains is related to the inappropriate use of antimicrobial drugs during treatment, as well as their use as growth promoters and for prophylaxis in veterinary medicine. In both cases, the antibiotic dosage is lower than that in therapeutic use, easing the appearance of mutations and/or acquisition of resistance genes due to selective pressure (CARATTOLI, 2008; SOUZA et al., 2010; ISHII et al., 2011).

Studies in different countries have reported the presence of cephalosporin and quinolone residues in animal-derived products such as meat, milk, and eggs. This situation increases the risk of emergence or selection of multidrug-resistant strains, such as those producing extended spectrum beta- 
lactamases (ESBL) and those resistant to quinolones (VRAGOVIĆ et al., 2011; WHO, 2011). By definition, ESBL-producing strains are resistant to penicillins, cephalosporins, and monobactams, but are sensitive to clavulanate (PEIRANO et al., 2011). These enzymes hydrolyze the beta-lactamic ring on the antibiotic, resulting in its deactivation. Currently, there are more than 370 known ESBL variants, most of which are encoded by plasmidial genes. The most frequently identified ESBL variants are TEM, SHV, OXA, and CTX-M (MINARINI et al., 2007; PEIRANO et al., 2011; LAGO et al., 2010).

Quinolones represent the antibiotic category used in the feeding of animals, thereby enabling the selection of resistant strains and consequently allowing these production animals to act as potential reservoirs and transmitters of multidrug-resistant bacteria to other animals, the environment and also to humans (WHO, 2011).

Resistance to quinolones can be caused by mutations in the genes encoding topoisomerase and DNA gyrase or by the presence of resistance plasmids. The latter mechanism is known as plasmid-mediated quinolone resistance (PMQR) (STRAHILEVITZ et al., 2009; KARAH et al., 2010; RODRÍGUEZ-MARTÍNEZ et al., 2011). Known PMQR mechanisms include: (1) the protection of gyrase and topoisomerases mediated by $q n r$ genes (ROBICSEK et al., 2006a; CATTOIR; NORDMANN, 2009; KARAH et al., 2010; STRAHILEVITZ et al., 2009; BAE et al., 2010; RODRÍGUEZ-MARTÍNEZ et al., 2011; ZHAO et al., 2010); (2) acetylation of quinolones and fluoroquinolones mediated by the $a a c\left(6^{\prime}\right)-I b$ cr gene (ROBICSEK et al., 2006b; CATTOIR; NORDMANN, 2009; JACOBY et al., 2009; KARAH et al., 2010; STRAHILEVITZ et al., 2009; RODRÍGUEZ-MARTÍNEZ et al., 2011); and (3) efflux pumps that expel quinolones and fluoroquinolones from the bacterial cell (CATTOIR; NORDMANN, 2009; MA et al., 2009; CATTOIR; NORDMANN, 2009; STRAHILEVITZ et al., 2009; BAE et al., 2010; KARAH et al., 2010; HERRERALEÓN et al., 2011).
In recent years, the frequency of isolating ESBLproducing and/or quinolone-resistant members of Enterobacteriaceae has increased because infections caused by these bacteria have limited therapeutic alternatives, causing grave concern among health authorities and institutions (ALDRED et al., 2014; CAUMO et al., 2010). Studies involving different animal species, including production animals and pets, have isolated Enterobacteriaceae family members producing different types of ESBLs, including TEM, SHV, and CTX (PEIRANO et al., 2011; LAGO et al., 2010).

Animals colonized by ESBL-producing and/ or PMQR harboring strains can be asymptomatic carriers, and invariably contribute to dissemination of these bacterial agents to other animals and/or humans. Alternatively, such animals can harbor an endogenous infection in unfavorable conditions, which have poor prognosis due to therapeutic failures, as measured by the expression of resistant genes to antibacterial drugs considered as the last therapeutic choice. The aim of this paper was to detect ESBL-producing and/or quinolone-resistant strains among Enterobacteriaceae family members isolated from healthy sheep and dogs from rural properties in the Umuarama region of Paraná, Brazil.

\section{Materials and Methods}

\section{Ethics committee}

This project was submitted to the Ethics Committee in Animal Experimentation (Comitê de Ética em Experimentação Animal - CEPEEA) at UNIPAR and was approved under protocol number $25113 / 2014$ on $25 / \mathrm{Jul} / 2013$.

\section{Location \& sampling}

A total of 81 swabs were collected from dogs and sheep, in the period of February to June 2014. Of these 81 swabs, 50 were collected from the rectal cavity of mixed breed sheep in their reproductive 
age (19 male and 31 female), and 31 from the oral cavity of mongrel dogs of age greater than one year (17 male and 14 female), from 11 small non-intense farming properties for sheep exploitation in the region of Umuarama, in the northeastern region in the state of Paraná, Brazil.

In the small rural properties studied, the sheep were raised for subsistence and as a source of income. Dogs were present in all these rural properties. No animal (whether sheep or dog) presented clinical signs of infectious disease upon physical examination.

\section{Collection of samples}

Rectal and oral samples were collected using swabs containing AIMES medium + activated charcoal (Copan Transystem $\bigcirc$, Italy), which were introduced in the rectal ampoule of each sheep, compressing it with rotating moves; and in the oral cavity of dogs, with circular and rotating moves performed in the gingiva and tongue regions. All samples were preserved and sent under refrigeration to the Laboratory of Preventive Veterinary Medicine and Public Health from the Masters Program in Animal Science at the Paranaense University (UNIPAR) for subsequent analysis.

\section{Bacterial isolation and identification}

Tubes containing $3.0 \mathrm{~mL}$ of brain heart infusion (BHI) medium were inoculated with the collected rectal and oral swabs and incubated for 24 hours at $37^{\circ} \mathrm{C}$. Subsequently, the cultures inoculated on Petri plates containing MacConkey agar supplemented with $10 \mu / \mathrm{mL}$ cefotaxime (CTX) and MacConkey agar supplemented with $50 \mu \mathrm{g} / \mathrm{mL}$ nalidixic acid (NAL) and incubated for 24 hours at $37^{\circ} \mathrm{C}$ to isolate colonies resistant to cephalosporin and quinolones. The isolated colonies were stored in BHI medium + glycerol $80 \%$ solution at $-20{ }^{\circ} \mathrm{C}$ for preservation.

\section{Biochemical identification of bacterial isolates}

Biochemical identification of bacteria belonging to the Enterobacteriaceae family was performed using the "Kit para Enterobactérias (Enterobacteria kit)" (NewProv®, Paraná, Brazil), following the manufacturer's recommendations.

\section{Phenotypic tests for antimicrobial susceptibility}

To determine the antibiotic resistance profile, the disk-diffusion in agar method was used, as per recommendations of the Clinical and Laboratory Standards Institute (CLSI, 2013). The disks tested were: gentamicin (GEN), ciprofloxacin (CIP), ceftazidime (CAZ), sulphazotrim (SUT), amikacin (AMI), aztreonam (ATM), chloramphenicol (CLO), ampicillin (AMP), tobramycin (TOB), cefoxitin (CFO), ceftriaxone (CRO), cefotaxime (CTX), tetracycline (TET), amoxicillin (AMO) and amoxicillin + clavulanate (AMC), imipenem (IMP), meropenem (MER), norfloxacin (NOR), and nalidixic acid (NAL). As the bacterial samples were isolated from animals, enrofloxacin (ENO) and ceftiofur (CEF) sensitivity was also tested, since they are antimicrobial drugs exclusively for veterinarian use.

Phenotypic tests for detection of ESBL-producing strains

The double-disk synergy test was performed to detect ESBL-producing strains. Briefly, disks containing CTX, CAZ, CRO, and ATM were distributed at a $20 \mathrm{~mm}$-distance from a disk containing AMC $(20 / 10 \mu \mathrm{g})$. Any increase or distortion in the zone of inhibition for one of the antibiotics towards the AMC disk was considered as suggestive for ESBL production (BRUN-BUISSON et al., 1987). 
Genotyping for the detection of ESBL and quinolones

The bacterial DNA was obtained by the boiling method and the ESBL genes bla $a_{\mathrm{TEM}}, b l a_{\mathrm{SHV}}$ and $b l a_{\text {СТХ-М }}$ (including $b l a_{\text {СТХ-М-2, }}$ bla $a_{\text {СТХ-М-8, }}$ and $b l a_{\mathrm{CTX}-\mathrm{M}-15}$ ) and quinolone-resistance genes ( $q n r$ and genes encoding acetylases and efflux pump) were identified by polymerase chain reaction (PCR). The primers and reaction conditions are described in Table 1.

Table 1. Initiators and annealing temperatures for the detection of bacterial resistance genes (ESBL and quinolones) used in the isolates from sheep and dog in rural properties exploiting sheep production in the region of Umuarama, Paraná, Brazil, 2014.

\begin{tabular}{|c|c|c|c|c|}
\hline Type & Gene & Primers $\left(5^{\prime}-3^{\prime}\right)$ & $\begin{array}{l}\text { Fragment }(\mathrm{pb}) / \\
\text { Temp. }\left({ }^{\circ} \mathrm{C}\right)\end{array}$ & Reference \\
\hline ESBL & $b l a_{\mathrm{TEM}}$ & $\begin{array}{l}\text { F- GAGTATTCAACATTTCCGTGTC } \\
\text { R- TAATCAGTGAGGCACCTATCT }\end{array}$ & $861 / 51$ & $\begin{array}{l}\text { Poirel et al. } \\
\quad(2000)\end{array}$ \\
\hline ESBL & $b l a_{\mathrm{SHV}}$ & $\begin{array}{l}\text { F- ATGCGTTATATTCGCCTGTG } \\
\text { R- GTTAGCGTTGCCAGTGCTCG }\end{array}$ & $573 / 53$ & $\begin{array}{l}\text { Minarini et al. } \\
\quad \text { (2007) }\end{array}$ \\
\hline ESBL & $b l a_{\text {СТХ-м }}$ & $\begin{array}{l}\text { F-CGCTTTGCGATGTGCAG } \\
\text { R-ACCCGCATATGCTTGTG }\end{array}$ & $544 / 56$ & $\begin{array}{l}\text { Bonnet et al. } \\
\quad(2000)\end{array}$ \\
\hline ESBL & $b l a_{\text {СTX-M-2 }}$ & $\begin{array}{l}\text { F- GCGACCTGGTTAACTACAATC } \\
\text { R- CGGTAGTATTGCCCTTAAGCC }\end{array}$ & $351 / 55$ & $\begin{array}{l}\text { Nedjai et al. } \\
\text { (2012) }\end{array}$ \\
\hline ESBL & $b l a_{\text {СТХ-М-8 }}$ & $\begin{array}{l}\text { F- CTGGAGAAAAGCAGCGGGGG } \\
\text { R-ACCCAGGATGTGGGTAGCCC }\end{array}$ & $320 / 55$ & $\begin{array}{l}\text { Minarini et al. } \\
\quad(2007)\end{array}$ \\
\hline ESBL & $b l a_{\text {CTX-M-15 }}$ & $\begin{array}{l}\text { F- CACACGTGGAATTTAGGGACT } \\
\text { R- GCCGTCTAAGGCGATAAACA }\end{array}$ & $550 / 56$ & $\begin{array}{l}\text { Muzaheed et } \\
\text { al. (2008) }\end{array}$ \\
\hline $\begin{array}{l}\text { Quinolonas } \\
\text { (PMQR) }\end{array}$ & $q n r A$ & $\begin{array}{l}\text { F- ATTTCTCACGCCAGGATTTG } \\
\text { R- TGCCAGGCACAGATCTTGAC }\end{array}$ & $468 / 53$ & $\begin{array}{l}\text { Jacoby et al. } \\
\text { (2009) }\end{array}$ \\
\hline $\begin{array}{l}\text { Quinolonas } \\
\text { (PMQR) }\end{array}$ & $q n r B$ & $\begin{array}{l}\text { F- CGACCTKAGCGGCACTGAAT } \\
\text { R- GAGCAACGAYGCCTGGTAGYTG }\end{array}$ & $513 / 53$ & $\begin{array}{l}\text { Jacoby et al. } \\
\text { (2009) }\end{array}$ \\
\hline $\begin{array}{l}\text { Quinolonas } \\
\text { (PMQR) }\end{array}$ & $q n r S$ & $\begin{array}{l}\text { F- ACTGCAAGTTCATTGAACAG } \\
\text { R- GATCTAAACCGTCGAGTTCG }\end{array}$ & $431 / 53$ & $\begin{array}{l}\text { Jacoby et al. } \\
\text { (2009) }\end{array}$ \\
\hline $\begin{array}{l}\text { Quinolonas } \\
\text { (Efluxo) }\end{array}$ & qерA & $\begin{array}{l}\text { F- AACTGCTTGAGCCCGTAGAT } \\
\text { R- GTCTACGCCATGGACCTCAC }\end{array}$ & $595 / 65$ & $\begin{array}{l}\text { Yum et al. } \\
\text { (2005) }\end{array}$ \\
\hline $\begin{array}{l}\text { Quinolonas } \\
\text { (Acetilase) }\end{array}$ & $a a c\left(6^{\prime}\right)-1 b$ & $\begin{array}{c}\text { F- TTGCGATGCTCTATGAGTCGCTA } \\
\text { R- CTCGAATGCCTGGCGTGTTT }\end{array}$ & $459 / 55$ & $\begin{array}{l}\text { Park et al. } \\
\text { (2006) }\end{array}$ \\
\hline
\end{tabular}

\section{Results and Discussion}

Analysis of the 81 isolated swabs led to the identification of four $(5.00 \%$; $4 / 81$ swabs $)$ bacterial isolates resistant to beta-lactams and/or quinolone antibiotic drugs. Among these isolates, three (75\%) were from sheep and one (25\%) was from a dog.

Strains resistant to beta-lactam antibiotics alone were identified in $1.25 \%(1 / 81$ swabs $)$ of the animals studied. Resistance only to quinolones was observed in $2.50 \%(2 / 81$ swabs $)$ and resistance to beta-lactams associated with quinolone resistance was seen in $1.25 \%(1 / 81)$ of the animals studied.
One $(3.20 \% ; 1 / 31$ swabs) ESBL-producing Escherichia coli was detected in the oral cavity swabs of dogs, and its resistance profile was confirmed by the double-disk synergic test and the detection of $b l a_{\text {CTX-M-15 }}$ and $b l a_{\text {TEM }}$ via PCR (Figure $1 \mathrm{~A}$ and Table 2).

In swabs collected from sheep, two Escherichia coli $(4.0 \% ; 2 / 50$ swabs $)$ strains resistant to all quinolones tested were identified. Both bacteria were isolated from female sheep and $q n r$ genes were detected in PCR analysis, confirming the profile found in the antibiogram (Table 2). 
ESBL resistance was determined in one Morganella morganii strain $(2.0 \% ; 1 / 50$ swabs) isolated from a male sheep, as confirmed by the presence of the $b l a_{\text {СТХ-м-2 }}$ gene detected by PCR. Other resistance genes were also identified in the same isolate, including the genes bla $a_{\mathrm{CMY}-2}$ and $q n r A$, granting AmpC-producing ability and PMQR to this strain (Figure 1B and Table 2).

The results of all the tests performed, as well as the resistance profiles obtained through antibiograms, are depicted in Figures 1 and 2 and described in Table 2.

The current antibiotic-therapy crisis has raised the need to generate public policies on the rational use of antibacterial drugs. Unfortunately, in Brazil, such actions have been directed mainly towards the use of antibiotics in human medicine. There still remain several discrepancies in the veterinarian sector, probably due to the lack of information on the impact of using antibacterial drugs in this area, as well as due to the lack of epidemiological studies that could provide panoramic insights into bacterial resistance in the residing microbiota in pets and production animals.

Phenotypic and genotypic tools such as the antibiogram and PCR, allow the monitoring of the dissemination of resistance determinants, identifying sources and animal housing multidrugresistant bacteria that can be transferred to human beings, the environment or other animals. The presence of gram-negative bacilli carrying ESBL genes in pets and production animals has been reported in several studies. However, these studies are limited in Brazil, especially on the oral cavity of pets, as current research has mainly focused on the analysis of feces and urine samples (MORENO et al., 2008; MA et al., 2009, 2012).

Some studies have detected high isolation frequencies of ESBL-producing $E$. coli in pets and production animals (MORENO et al., 2008; MA et al., 2009, 2012). The isolates harbored bla ${ }_{\text {СтХ-м-1, }}$ $b l a_{\text {СТХ-М-2 }}$ bla $a_{\text {СТХ-м-8 }}$ or bla $a_{\text {СТХ-м-15 }}$ genes and, in some cases, a single strain presented more than one type of ESBL gene, with the presence of bla ${ }_{\text {CTX-like }}$ associated with other ESBL genes, such as bla (MORENO et al., 2008).

A study performed by Moreno et al. (2008) identified a $20 \%$ prevalence of ESBL-producing strains in feces and urine from pets. A few isolates presented more than one ESBL variant. This paper presents alarming data on beta-lactam antibiotic-resistant strains in pets, with the threat of dissemination of such multidrug-resistant strains via the feces of these animals into the environment they live in.

Figure 1. A) ESBL production in Escherichia coli (P1C4 strain) isolated from the oral cavity of a dog. The distortion in inhibition halos indicated by the arrows highlight ESBL production. B) Double-disk test for the Morganella morganii strain (P4O11 Strain), isolated from a male sheep, indicating the production of AmpC. The sheep and dog originated from a rural property in the region of Umuarama, Paraná, Brazil, 2014.
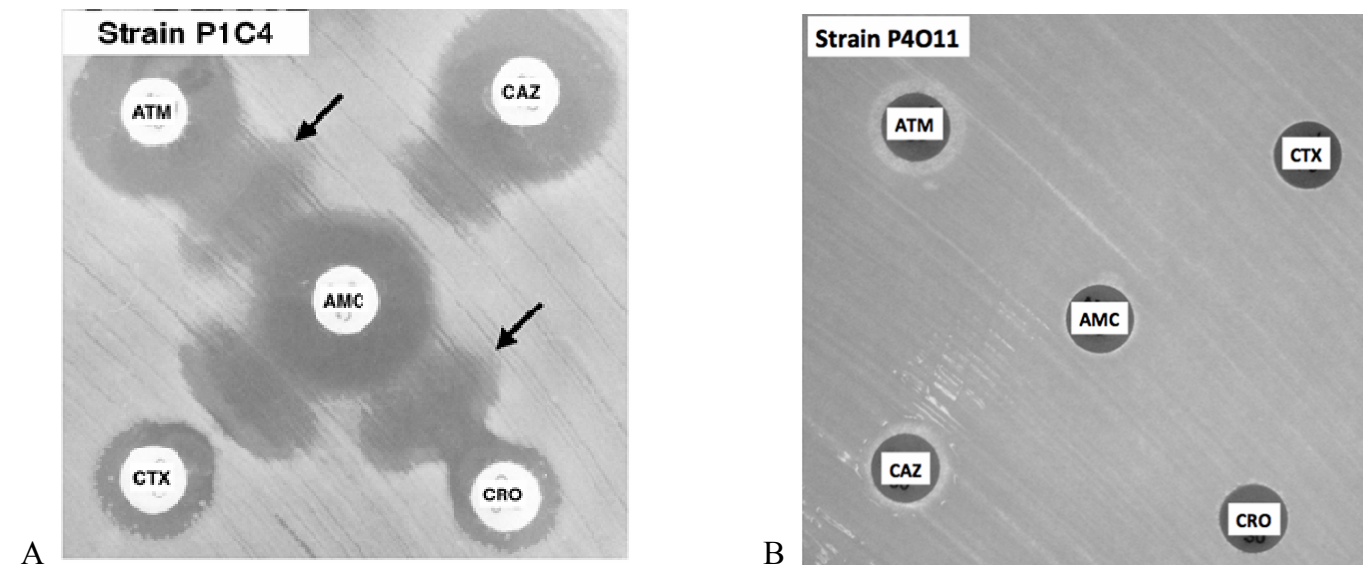


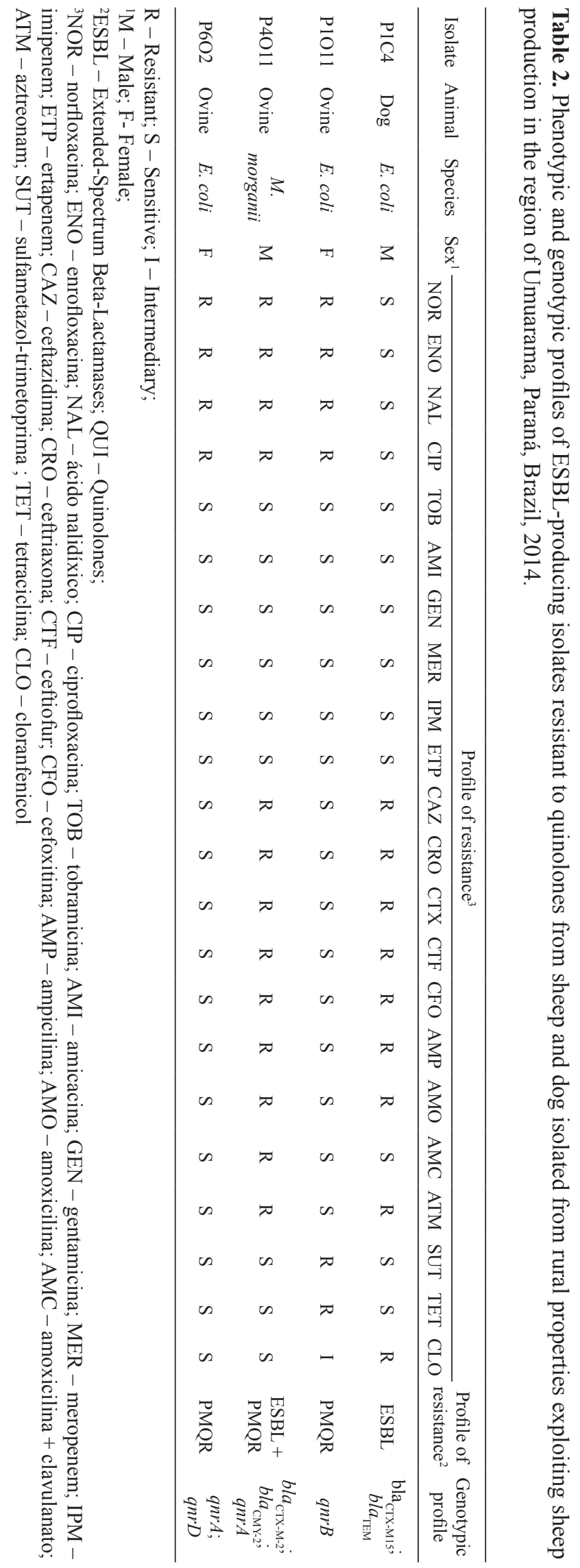


Phenotypic and genotypic data from the isolates found in the work of Moreno et al. (2008) corroborate the results of the present study, as the E. coli ( $\mathrm{P} 1 \mathrm{C} 4)$ strain isolated from the oral cavity of dogs presented the $b l a_{\text {СTX-M-15 }}$ and $b l a_{\text {TEM }}$ genes. On the other hand, the low isolation frequency suggests that such a bacterium may be present only transitorily in the oral cavity of dogs.

Nevertheless, the presence of ESBL-producing $E$. coli found in a dog oral sample indicates a high risk of contamination between animals and humans, since there is frequent contact with dog saliva. Moreover, as these animals were living in rural properties, they may acquire these strains from other animals or even human beings, as described by Moura et al. (2009), who studied the crossedtransmission of enterobacteria between humans and pets.

Along with beta-lactam antibiotics, quinolones are also used for therapeutic purposes, prophylaxis or growth promotion in animal production environments (AARESTRUP, 2005). Abuse in their use has led to selection and development of quinolone-resistant bacteria, compromising the treatment of infectious diseases in these animals (AARESTRUP, 2005; GIBBS et al., 2006; MA et al., 2009; HERRERA-LEÓN et al., 2011).

Several studies have shown the emergence and dissemination of PMQR in enterobacteria isolated from pets, production and wild animals (LIU et al., 2008; HUANG et al., 2009; MA et al., 2009; POMBA et al., 2009; ASAI et al., 2010; GIBSON et al., 2010a, 2010b; FORTINI et al., 2011). These data indicate that these animals are an important reservoir for PMQR-resistance genes and they can act as possible transmission vectors for human beings, the environment and other animals (ROBICSEK et al., 2006a; GIBBS et al., 2006; HAWKEY et al., 2009).

Quinolone resistance attributed to the presence of $q n r$ genes was detected in $2.50 \%$ (2/81 swabs) of sheep and dogs studied, and E. coli was isolated in both cases. Genes $q n r A$ and $q n r D$ were identified in these two strains, with one of them presenting the two subtypes.

The results indicate a low prevalence of quinolone resistance. However, the resistance profile in enterobacteria isolated from pets is similar to the profile of quinolone-resistant enterobacteria isolated from humans, indicating that animalhuman-environment cross-transmission relations are possible (POMBA et al., 2009; FERREIRA et al., 2010a, 2010b; ANTUNES et al., 2011).

Quinolone-resistant genes have been identified in enterobacteria isolated from different animal species, including commensal microbiota of pets and production animals, suggesting that these animals are important reservoirs for such bacteria (NOVAIS et al., 2005; MACHADO et al., 2008).

Additionally, an association between $q n r$ and ESBL production in single enterobacteria has been reported in a few studies (POMBA et al., 2009). The present study has identified a $M$. morganii strain producing ESBL, AmpC and resistance to quinolones isolated from the rectal cavity of a male sheep, with its phenotypic and genotypic profile, corroborating results from studies performed in humans, pets and production animals around the world. AmpC production was confirmed by means of the antibiogram profile and by the detection of the $b l a_{\mathrm{CMY}-2}$ gene through PCR. The presence of this gene enables this strain to be resistant to AMC, as AmpC-type beta-lactamase producing bacteria can inhibit the action of clavulanate (MACHADO et al., 2006; TOUATI et al., 2008; MINARINI et al., 2008; CRÉMET et al., 2011; PANIAGUA et al., 2010; HUANG et al., 2009; MAHROUKI et al., 2013).

Importantly, all resistance determinants found in the studied strains are coded by mobile genetic elements, easing the dissemination of these resistance genes among strains of the same species, as well as among different species within the microbiota of an animal. 


\section{Conclusion}

This study suggests a possibility of direct and/or indirect transmission of resistant bacteria through human-animal contact, as well as their transmission to the environment, as the bacteria isolated from animals and human beings present the same phenotypic and genotypic profiles. The results underscore the need for further molecular studies to characterize the genes coding for the acquired resistance to quinolones in other environmental niches, detect the emergence of new resistance genes and monitor their dissemination among different bacteria and environmental niches. Only then will it be possible to design and implement efficient measures to control the dissemination of multi-resistant bacteria (including animal to human transmission) and minimize the risk for human health.

\section{Acknowledgments}

The authors express their gratitude to UNIPAR for granting the funds for this study.

\section{References}

AARESTRUP, F. Veterinary drug usage and antimicrobial resistance in bacteria of animal origin. Basic and Clinical Pharmacology and Toxicology. Copenhagen, v. 96, n. 4, p. 271-281, 2005.

ALDRED, K. I.; KERNS, R. I.; OSHEROFF, N. Mechanism of quinolone action and resistance. Biochemistry. Washington, v. 53, n. 10, p. 1565-1574, 2014.

ANTUNES, P.; MOURÃO, J.; MACHADO, J.; PEIXE, L. First description of qnrS1-IncN plasmid in a ST11 Salmonella enteritidis clinical isolate from Portugal. Diagnostic Microbiology and Infectious Diseases. New York, v. 69, n. 4, p. 463-465, 2011.

ASAI, T.; SATO, C.; MASANI, K.; USUI, M.; OZAWA, M.; OGINO, T.; AOKI, H.; SAWADA, T.; IZUMIYA, H.; WATANABE, H. Epidemiology of plasmid-mediated quinolone resistance in Salmonella entericaserovarTyphimurium isolates from foodproducing animals in Japan. Gut Pathogens, London, v. 2, n. 17, p. 2-5, 2010.
BAE, I. K.; PARK, I.; LEE, J. J.; SUN, H. I.; PARK, K. S.; LEE, J. E.; AHN, J. H.; LEE, S. H.; WOO, G. I. Novel variants of the qnrB gene, qnrB22 and qnrB23, in Citrobacter werkmanii and Citrobacter freundii. Antimicrobial Agents and Chemotherapy, Washington, v. 54, n. 7, p. 3068-3069, 2010.

BONNET, R.; SAMPAIO, J. L. M.; LABIA, R.; DE CHAMPS, C.; SIROT, D.; CHANAL, C.; SIROT, J. A novel CTX-M $\beta$-lactamase (CTX-M-8) in cefotaximeresistant Enterobacteriaceae isolated in Brazil. Antimicrobial Agents and Chemotherapy, Washington, v. 44, n. 7, p. 1936-1942, 2000.

BRUN-BUISSON, C.; LEGRAND, P.; PHILIPPON, A.; MONTRAVERS, F.; ANSQUER, M.; DUVAL, J. Transferable enzymatic resistance to third-generation cephalosporins during nosocomial outbreak of multiresistant Klebsiella pneumoniae. Lancet, London,v. 8, n. 2 p. 302-306, 1987.

CARATTOLI,A.Animal reservoirs for extended spectrum beta-lactamase producers. Clinical Microbiology and Infection, Malden, v. 14, n. 1, p. 117-123, 2008.

CATTOIR, V.; NORDMANN, P. Plasmid-mediated quinolone resistance in Gram-negative bacterial species: an update. Current Medicinal Chemistry, Amsterdã, v. 16, n. 8, p. 1028-1046, 2009.

CAUMO, K.; DUARTE, M.; CARGNIN, S. T.; RIBEIRO, V. B.; TASCA, T.; MACEDO, A. J. Resistencia bacteriana: no meio ambiente e implicações na clínica hospitalar. Revista Liberato, Novo Hamburgo, v. 11, n. 16, p. 89-188, 2010.

CLINICAL AND LABORATORY STANDARDS INSTITUTE - CLSI. Performance standards for antimicrobial susceptibility testing: twenty-third informational supplement M100-S23. Wayne: CLSI, 2013.

CRÉMET, L.; CAROFF, N.; DAUVERGNE, S.; REYNAUD, A.; LEPELLETIER, D.; CORVEC, S. Prevalence of plasmid-mediated quinolone resistance determinants in ESBL Enterobacteriaceae clinical isolates over a 1-year period in a French hospital. PathologieBiologie, Paris, v. 59, n. 3, p. 151-156, 2011.

FERREIRA, S.; PARADELA, A.; VELEZ, J.; RAMALHEIRA, E.; WALSH, T. R.; MENDO, S. Carriage of qnrA1 and qnrB2, blaCTX-M15, and complex class 1 integron in a clinical multiresistant Citrobacter freundii isolate. Diagnostic Microbiology and Infectious Diseases, New York, v. 67, n. 2, p. 188-190, 2010a.

FERREIRA, S.; TOLEMAN, M.; RAMALHEIRA, E.; SILVA, G. I. da; WALSH, T. R.; MENDO, S. First description of Klebsiella pneumoniae clinical isolates 
carrying both qnrA and qnrB genes in Portugal. International Journal of Antimicrobial Chemotherapy, London, v. 35, n. 6, p. 584-586, 2010b.

FORTINI, D.; FASHAE, K.; GARCÍA-FERNÁNDEZ, A.; VILLA, L.; CARATTOLI, A. Plasmid-mediated quinolone resistance and beta-lactamases in Escherichia coli from healthy animals from Nigeria. Journal of Antimicrobial Chemotherapy, London, v. 66, n. 6, p. 1269-1272, 2011.

GIBBS, S. G.; GREEN, C. F.; TARWATER, P. M.; MOTA, L. C.; MENA, K. D.; SCARPINO, P. V. Isolation of antibiotic-resistant bacteria from the air plume downwind of a swine confined or concentrated animal feeding operation. Environmental Health Perspectives, New York, v. 114, n. 7, p. 1032-1037, 2006.

GIBSON, J. S.; COBBOLD, R. N.; KYAW-TANNER, M. T.; HEISIG, P.; TROTT, D. J. Fluoroquinolone resistance mechanisms in multidrug-resistant Escherichia coli isolated from extraintestinal infections in dogs. Veterinary Microbiology, Amsterdam, v. 146, n. 1-2, p. 161-166, 2010a.

Identification of Qnr and AAC(6')-Ibcr plasmid-mediated fluoroquinolone resistance determinants in multidrug-resistant Enterobacter spp. isolated from extraintestinal infections in companion animals. Veterinary Microbiology, Amsterdam, v. 143, n. 2-4, p. 329-336, 2010 b.

HAWKEY, P. M.; JONES, A. M. The changing epidemiology of resistance. Journal of Antimicrobial Chemotherapy, London, v. 64, n. 1, p. i3-i10, 2009.

HERRERA-LEÓN， S.; GONZÁLEZ-SANZ， R.; HERRERA-LEÓN, L.; ECHEITA, M.A. Characterization of multidrug-resistant Enterobacteriaceae carrying plasmid-mediated quinolone resistance mechanisms in Spain. Journal of Antimicrobial Chemotherapy, London, v. 66, n. 2, p. 287-290, 2011.

HUANG, S. Y.; DAI, L.; XIA, L. N.; DU, X. D.; QI, Y. H.; LIU, H. B.; WU, C. M.; SHEN, J. Z. Increased prevalence of plasmid-mediated quinolone resistance determinants in chicken Escherichia coli isolates from 2001 to 2007. Foodborne Pathogens and Disease, New York, v. 6, n. 10, p. 1203-1209, 2009.

ISHII, J. B.; FREITAS, J. C.; ARIAS, M. V. B. Resistência de bactériasisoladas de cães e gatos no hospital veterinário da Universidade Estadual de Londrina (2008-2009). Pesquisa Veterinária Brasileira, Rio de Janeiro, v. 31, n. 6, p. 533-537, 2011.

JACOBY, G. A.; GACHARNA, N.; BLACK, T. A.; MILLER, G. H.; HOOPER, D. C. Temporal Appearance of Plasmid-Mediated Quinolone Resistance Genes.
Antimicrobial Agents and Chemotherapy, Washington, v. 53, n. 4, p. 1665-1666, 2009.

JONG,A. de; STEPHAN, B.; SILLEY, P. Fluoroquinolone resistance of Escherichia coli and Salmonella from healthy livestock and poultry in the EU. Journal of Applied Microbiology, Oxford,v. 112, n. 2, p. 239-245, 2011.

KARAH, N.; POIREL, L.; BENGTSSON, S.; SUNDQVIST, M.; KAHLMETER, G.; NORDMANN, P.; SUNDSFJORD, A.; SAMUELSEN, Ø. Plasmidmediated quinolone resistance determinants qnr and aac(6')- Ib-cr in Escherichia coli and Klebsiella spp. from Norway and Sweden. Diagnostic Microbiology and Infectious Diseases, New York, v. 66, n. 4, p. 425-431, 2010.

LAGO, A.; FUENTERIA, S. R.; FUENTEFRIA, D. B. Enterobactérias produtoras de ESBL em Passo Fundo Estado do Rio Grande do sul, Brasil. Revista da Sociedade Brasileira de Medicina Tropical, Rio de Janeiro, v. 43, n. 4, p. 430-434, 2010.

LIU, J. H.; DENG, Y. T.; ZENG, Z. L.; GAO, J. H.; CHEN, L.; ARAKAWA, Y.; CHEN, Z. L. Coprevalence of plasmid-mediated quinolone resistance determinants QepA, Qnr and AAC(6 ')-Ib-cr among 16S rRNA methylase RmtB-producing Escherichia coli isolates from pigs. Antimicrobial Agents and Chemotherapy, Washington, v. 52, n. 1, p. 2992-2993, 2008.

MA, J.; LIU, J. H.; LV, L.; ZONG, Z.; SUN, E. T.; ZHENG, A. L.; CHEN, Z.; ZENG, Z. L. Characterization of extended-spectrum beta-lactamase genes found among Escherichia coli isolates from duck and environmental samples obtained on a duck farm. Applied and Environmental Microbiology, Washigton, v. 78, n. 10, p. 3668-3673, 2012.

MA, J.; ZENG, Z.; CHEN, Z.; XU, X.; WANG, X.; DENG, Y.; LÜ, D.; HUANG, L.; ZHANG, Y.; LIU, J.; WANG, M. High prevalence of plasmid-mediated quinolone resistance determinants qnr, aac(6 ')-Ib-cr, and qepA among ceftiofur-resistant Enterobacteriaceae isolates from companion and food-producing animals. Antimicrobial Agents and Chemotherapy, Washigton, v. 53, n. 2, p. 519-524, 2009.

MACHADO, E.; COQUE, T. M.; CANTÓN, R.; BAQUERO, F.; SOUSA, J. C.; PEIXE, L. Dissemination in Portugal of CTX-M-15-, OXA-1-, and TEM1-producing Enterobacteriaceae strains containing the aac(6')-Ib-cr gene, which encodes an aminoglycosideand fluoroquinolone-modifying enzyme. Antimicrobial Agents and Chemotherapy, Washington, v. 50, n. 9, p. 3220-3221, 2006. 
MACHADO, E.; COQUE, T. M.; CANTÓN, R.; SOUSA, J. C.; PEIXE, L. Antibiotic resistance integrons and extended-spectrum beta- lactamases among Enterobacteriaceae isolates recovered from chickens and swine in Portugal. Journal of Antimicrobial Chemotherapy, London, v. 62, n. 2, p. 296-302, 2008.

MAHROUKI, S.; PERILLI, M.; BOUROUIS, A.; CHIHIFERJANI, M. Prevalence of quinolone resistance determinant qnrA6 among broad- and extended-spectrum beta-lactam-resistant Proteus mirabilis and Morganella morganii clinical isolates with sul1-type class 1 integron association in a Tunisian Hospital. Scandinavian Journal of Infectious Diseases, Stockholm, v. 45, n. 8, p. 600605, 2013.

MINARINI, L. A.; POIREL, L.; CATTOIR, V.; DARINI, A. L.; NORDMANN, P. Plasmid-mediated quinolone resistance determinants among enterobacterial isolates from outpatients in Brazil. Journal of Antimicrobial Chemotherapy, London, v. 62, n. 3, p. 474-478, 2008.

MINARINI, L. A. R.; GALES, A. C.; PALAZZO, I. C. V.; DARINI, A. L. C. Prevalence of communityoccurring extended spectrum beta-lactamase-producing Enterobacteriaceae in Brazil. Current Microbiology, Berlim, v. 54, n. 5, p. 335-341, 2007.

MORENO, A.; PELlO, E. T.; GUGGIANA, D.; DOMÍNGUEZ, M.; GONZÁLEZ, G. Extended-spectrum beta-lactamases belonging to CTX-M group produced by Escherichia coli strains isolated from companion animals treated with enrofloxacin. Veterinary Microbiology, Amsterdam, v. 129, n. 1-2, p. 203-208, 2008.

MOURA, R. A.; SIRCILI, M. P.; LEOMIL, L.; MATTÉ, M. H.; TRABULSI, L. R.; ELIAS, W. P.; IRINO, K.; PESTANA DE CASTRO, A. F. Clonal relationship among atypical enteropathogenic Escherichia coli strains isolated from different animal species and humans. Applied and Environmental Microbiology, Washington, v. 75, n. 23, p. 7399-408, 2009.

MUZAHEED, Y.; ADAMS-HADUCH, J. M.; ENDIMIANI, A.; SIDJABAT, H. E.; GADDAD, S. M.; PATERSON, D. L. High prevalence of CTX-M-15producing Klebsiella pneumoniae among inpatients and outpatients with urinary tract infection in Southern India. Journal of Antimicrobial Chemotherapy, London, v. 61, n. 6, p. 1393-1394, 2008.

NEDJAI, S.; BARGUIGUA, A.; DJAHMI, N.; JAMALI, L.; ZEROUALI, K.; DEKHIL, M.; TIMINOUNI, M. Prevalence and characterization of extended spectrum $\beta$-lactamases in Klebsiella - Enterobacter - Serratia group bacteria, in Algeria. Médecine et Maladies Infectieuses, Grenoble, v. 42, n.1, p. 20-29, 2012.
NOVAIS, C.; COQUE, T. M.; COSTA, M. J.; SOUSA, J. C.; BAQUERO, F.; PEIXE, L. V. High occurrence and persistence of antibiotic-resistant enterococci in poultry food samples in Portugal. Journal of Antimicrobial Chemotherapy, London, v. 56, n. 6, p. 1139-1143, 2005.

PANIAGUA, R.; VALVERDE, A.; COQUE, T. M.; BAQUERO, F.; CANTÓN, R. Assessment of prevalence and changing epidemiology of extended-spectrum betalactamase-producing Enterobacteriaceae fecal carriers using a chromogenic medium. Diagnostic Microbiology and Infectious Diseases, New York, v. 67, n. 4, p. 376379, 2010.

PARK, C.; ROBICSEK, A.; JACOBY, G. A.; SAHM, D.; HOOPER, D. Prevalence in the United States of aac(6')Ib-cr encoding a ciprofloxacin-modifying enzyme. Antimicrobial Agents and Chemotherapy, Washington, v. 50, n. 11, p. 3953-3955, 2006.

PEIRANO, G.; ASENSI, M. D.; PITONDO-SILVA, A.; PITOUT, J. D. Molecular characteristics of extendedspectrum $\beta$-lactamase-producing Escherichia coli from Rio de Janeiro, Brazil. Clinical Microbiology and Infection, London, v. 17, n. 7, p. 1039-1043, 2011.

POIREL, L.; LE THOMAS, I.; NAAS, T.; KARIM, A.; NORDMANN, P. Biochemical Sequence Analyses of GES-1, a Novel Class A ExtendedSpectrum $\beta$-Lactamase, and the Class 1 Integron In52 from Klebsiella pneumoniae. Antimicrobial Agents and Chemotherapy, Washington, v. 44, n. 3, p. 622-632, 2000.

POMBA, C.; FONSECA, J. D. da; BAPTISTA, B. C.; CORREIA, J. D.; MARTÍNEZ-MARTÍNEZ, L. Detection of the pandemic O25-ST131 human virulent Escherichia coli CTX-M-15-producing clone harboring the qnrB2 and aac(6')-Ib-cr genes in a dog. Antimicrobial Agents and Chemotherapy, Washington, v. 53, n. 1, p. 327-328, 2009.

ROBICSEK, A.; JACOBY, G. A.; HOOPER, D. C. The worldwide emergence of plasmid-mediated quinolone resistance. Lancet Infectious Diseases, New York, v. 6, n. 10, p. 629-640, 2006a.

Fluoroquinolone-modifying enzyme: a new adaptation of a common aminoglycoside acetyltransferase. Nature Medicine Microbiology, Londres, v. 12, n. 1, p. 83-88, 2006b.

RODRÍGUEZ-MARTÍNEZ，J. M.; CANO， M. E.; VELASCO, C.; MARTÍNEZ-MARTÍNEZ, L.; PASCUAL, A. Plasmid-mediated quinolone resistance: an update. Journal of Infection and Chemotherapy, Tokyo, v. 17, n. 2, p. 149-182, 2011. 
SOUZA, R. B.; MAGNANI, M.; OLIVEIRA, T. C. R. M. Mecanismos de resistência as quinolonasem Salmonellla spp. Semina: Ciências Agrárias, Londrina, v. 31, n. 2, p. 413-428, 2010.

STRAHILEVITZ, J.; JACOBY, G. A.; HOOPER, D. C.; ROBICSEK, A. Plasmid-mediated quinolone resistance: a multifaceted threat. Clinical Microbiology Reviews, Washington, v. 22, n. 4, p. 664-689, 2009.

TEO, J.; CAI, Y.; TANG, S.; LEE, W.; TAN, T. Y.; TAN, T. T.; KWA, A. L. Risk factors, molecular epidemiology and outcomes of ertapenem resistant, carbapenemsusceptible Enterobacteriaceae: a case-case-control study. Critical Care, Londres, v. 7, n. 3, p. e34254 , 2012.

TOUATI, A.; BRASME, L.; BENALLAOUA, S.; GHAROUT, A.; MADOUX, J.; DE CHAMPS, C. First report of qnrB-producing Enterobacter cloacae and qnrA- producing Acinetobacterbaumannii recovered from Algerian hospitals. Diagnostic Microbiology and Infectious Diseases, New York, v. 60, n. 3, p. 287-290, 2008.

VRAGOVIĆ, N.; BAZULIĆ, D.; NJARI, B. Risk assessment of streptomycin and tetracycline residues in meat and milk on Croatian market. Food and Chemical Toxicology, Philadelphia, v. 49, n. 2, p. 352-355, 2011.
WORLD HEALTH ORGANIZATION - WHO. Antimicrobial resistance. Global Report on Survillance. Geneva: WHO Library, 2014. Available at: <http:// aphttp://apps.who.int/iris/bitstream/10665/112642/1/978 9241564748eng.pdf $>$. Accessed at: 1 dec. 2014.

- Tackling antibiotic resistance from a food safety perspective in Europe 2011. Copenhagen: WHO Library, 2011. Available at: <http://etal.euro.who.int/ data/assets/pdf_file/0005/136454/e94889.pdf?ua=1>. Accessed at: 1 dez. 2014.

YUM, J.; KIM, S.; YONG, D.; LEE, K.; CHO, S. N.; CHONG, E. Emergence and wide dissemination of CTX-M-type ESBLs, and CMY-2- and DHA-1-type AmpC beta-lactamases in Korean respiratory isolates of Klebsiella pneumoniae. Journal of Korean Medicine and Science, Korean, v. 20, n. 6, p. 961-965, 2005.

ZHAO, J.; CHEN, Z.; CHEN, S.; DENG, Y.; LIU, Y.; TIAN, W.; HUANG, X.; WU, C.; SUN, Y.; SUN, Y.; ZENG, Z.; LIU, J. H. Prevalence and dissemination of oqxAB in Escherichia coli isolates from animals, farmworkers, and the environment. Antimicrobial Agents and Chemotherapy, Washington, v. 54, n. 10, p. 4219-24, 2010. 